This manuscript has been submitted and accepted for publication in Science of the Total Environment. The 'Peer-reviewed Publication DOI' is 10.1016/j.scitotenv.2020.140105. Please feel free to contact any of the authors. We welcome feedback. 


\title{
Methane concentrations in streams reveal gas leak discharges in regions of oil, gas, and coal development
}

\author{
Josh Woda ${ }^{\text {a }}$, Tao Wen ${ }^{\text {b }}$, Jacob Lemon ${ }^{\text {c }}$, Virginia Marcon a,
}

Charles M. Keeports ${ }^{d}$, Fred Zelt ${ }^{\mathrm{e}}$, Luanne Y. Steffy ${ }^{\mathrm{f}}$, Susan L. Brantley a,b

${ }^{a}$ Department of Geosciences, Pennsylvania State University, University Park, PA 16802, USA

${ }^{b}$ Earth and Environmental Systems Institute, Pennsylvania State University, University Park, PA 16802, USA

${ }^{\mathrm{c}}$ Trout Unlimited, Arlington, VA 22209, USA

${ }^{\mathrm{d}}$ USDA Forest Service, Allegheny National Forest, Warren, PA 16365, USA

${ }^{\mathrm{e}}$ Independent Geoscientist, Pittsburgh, PA, 15106, USA

${ }^{\mathrm{f}}$ Susquehanna River Basin Commission, Harrisburg, PA 17110, USA 


\section{Graphical Abstract}

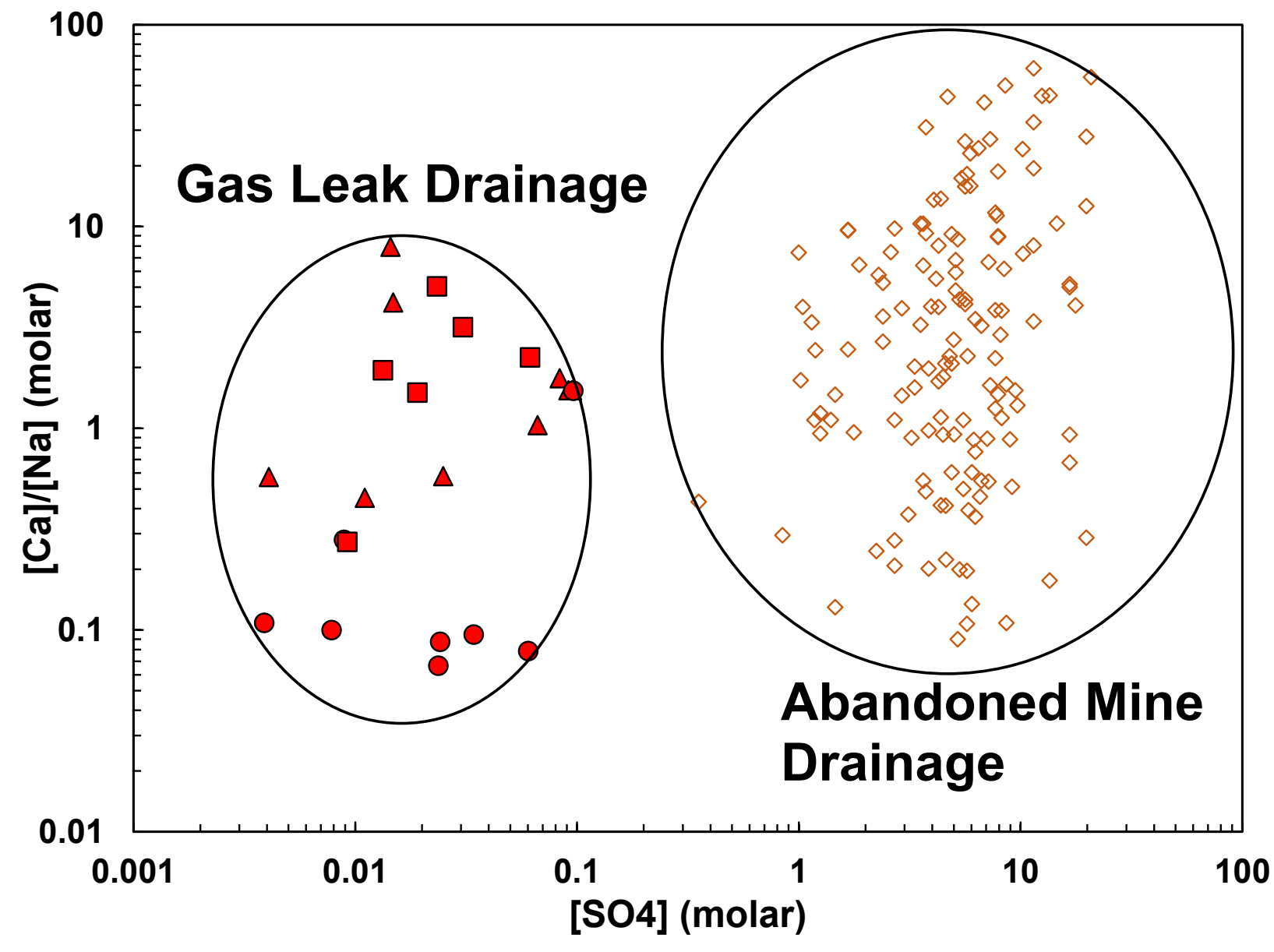




\begin{abstract}
As natural gas has grown in importance as a global energy source, leakage of methane $\left(\mathrm{CH}_{4}\right)$ from wells has sometimes been noted. Leakage of this greenhouse gas is important because it affects groundwater quality and, when emitted to the atmosphere, climate. We hypothesized that streams might be most contaminated by $\mathrm{CH}_{4}$ in the northern Appalachian Basin in regions with the longest history of hydrocarbon extraction activities. To test this, we searched for $\mathrm{CH}_{4}-$ contaminated streams Basin. Methane concentrations $\left(\left[\mathrm{CH}_{4}\right]\right)$ for 529 stream sites are reported, in New York, West Virginia and mostly Pennsylvania. Despite targeting contaminated areas, the median $\left[\mathrm{CH}_{4}\right], 1.1 \mu \mathrm{g} / \mathrm{L}$, was lower than a recently identified threshold indicating potential contamination, $4.0 \mu \mathrm{g} / \mathrm{L}$. $\left[\mathrm{CH}_{4}\right]$ values were higher in a few streams because they receive high$\left[\mathrm{CH}_{4}\right]$ groundwaters, often from upwelling seeps. By analogy to the more commonly observed type of groundwater seep known as abandoned mine drainage (AMD), we introduce the term, "gas leak discharge" (GLD) for these waters where they are not associated with coal mines. GLD and AMD, observed in all parts of the study area, are both $\mathrm{CH}_{4}$-rich. Surprisingly, the region of oldest and most productive oil / gas development did not show the highest median for stream $\left[\mathrm{CH}_{4}\right]$. Instead, the median was statistically highest where dense coal mining was accompanied by conventional and unconventional oil and gas development, emphasizing the importance of $\mathrm{CH}_{4}$ contamination from coal mines into streams.
\end{abstract}

Keywords: Natural gas, shale gas, coal, methane, water quality 


\section{Introduction}

A common water quality impact related to shale gas development is contamination by fugitive migration of natural gas (e.g., Brantley et al., 2014; Cahill et al., 2017; Hammond et al., 2020; US EPA, 2016; Vengosh et al., 2014; Wen et al., 2017, 2016). Specifically, methane, $\mathrm{CH}_{4}$, like other forms of dissolved organic carbon (Blothe and Roden, 2009; Bruun et al., 2010), can reduce and mobilize metals that are deleterious to aqueous ecosystems when it enters aquifers (Woda et al., 2018). The mobilization of metals in these waters is somewhat similar to that observed in waters affected by acids from pyrite oxidation (Roden et al., 2012), but the phenomenon has only been studied by a few researchers (e.g., Cahill et al., 2018, 2017; Humphrey et al., 2018; Woda et al., 2018). Natural gas leakage is also problematic when $\mathrm{CH}_{4}$ escapes to the atmosphere, as this greenhouse gas has a warming potential 84 times that of carbon dioxide on a 20 -year timescale (Myhre et al., 2013). Furthermore, methane is an explosion hazard when it accumulates in high concentrations $(50,000$ parts per million by volume) within enclosed areas (Gorody, 2012). The extent and impact of methane leakage is unknown even though more than 4 million oil and gas wells have been drilled worldwide since the mid-1800s (Davies et al., 2014). To explore the impacts from leaking methane into water resources, we measured hydrochemistry of streams and seeps in the northern Appalachian Basin where the earliest commercial oil well was drilled in 1859

and drilling continues today into both conventional and unconventional (shale) reservoirs (PA DEP, 2018b). We hypothesized that streams might be most contaminated by $\mathrm{CH}_{4}$ in the region with the longest history of hydrocarbon extraction activities. 


\section{Hydrocarbon Development in Pennsylvania}

We focused on Pennsylvania (PA), the center of the current Marcellus shale development boom, because it also has a long history of conventional hydrocarbon development. From 2004 to 2019, about 12,300 new unconventional shale gas wells were drilled in PA, but $>200,000$ other active, plugged, abandoned or regulatory-inactive conventional oil and gas wells are also located in the state according to the state regulator of oil and gas (Figure 1; PA DEP, 2018c). Of the abandoned wells, only 12,000 are recorded in the PA Department of Environmental Protection (PA DEP) online database with known locations. Many of these are in the Allegheny National Forest in the northwestern part of the state (PA DEP, 2018a). If injection wells for water flooding as an enhanced oil recovery method are included in the state inventory, as many as $470,000-$ 750,000 oil and gas wells may have been abandoned in total, again with many locations unknown (Kang et al., 2016).

Most of the older wells are located in northwestern PA (Dilmore et al., 2015) and they date to as early as 1859 when the first commercial oil well in the world was drilled in Titusville, PA. All wells abandoned before 1957 may be plugged improperly by today's standards. For example, legislation passed in 1921 in PA required wells drilled through coal seams to eventually be plugged with “well-seasoned, round wooden plugs" (Oil and Gas Wells, Drilling Regulating Act of May 17, 1921, 1921). Since 1957, drilling, casing, cementing and plugging standards have improved drastically (Carter et al., 2011; Dilmore et al., 2015). 


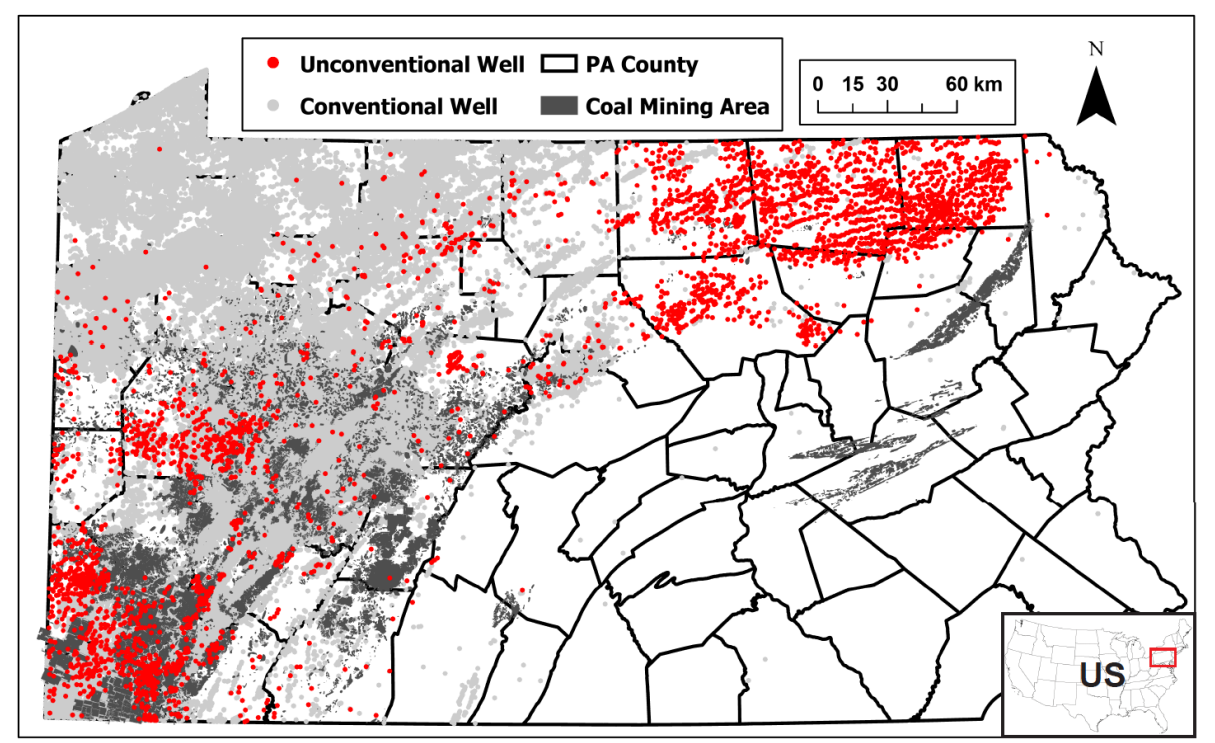

Figure 1: Location of oil/gas wells drilled in conventional (light grey) and unconventional reservoirs (red), and areas with coal mining (dark grey) in PA. Map layers compiled by Wen et al. (2019) from PA DEP data (PA DEP, 2018b, 2018a).

In addition to oil and gas development, PA has a long history of coal mining, dating to the 1700s. Centuries of mining have led to over 5,000 abandoned coal mines (PA DEP, 2018a). Disturbance related to mining often causes interactions of oxygen-rich waters with pyrite (Rose and Cravotta, 1998) that commonly discharges as abandoned mine drainage (AMD). AMDimpacted surface or ground water typically is characterized by low $\mathrm{pH}$, and high total dissolved solids (TDS), including high concentrations of heavy metals and sulfate (Akcil and Koldas, 2006).

\section{Rationale for Stream Sampling for $\mathrm{CH}_{4}$}

Determination of the source of $\mathrm{CH}_{4}$ leakage into waterways can be ambiguous because of the many sources of natural gas. For example, micro-organisms naturally produce biogenic $\mathrm{CH}_{4}$ in shallow systems (Whiticar, 1999), and heat-induced breakdown of kerogen naturally produces $\mathrm{CH}_{4}$ thermogenically at greater depths. Gaseous or dissolved $\mathrm{CH}_{4}$ can migrate to the surface or within shallow systems along faults, fractures, porous layers, and/or other pathways from great depth (Darrah et al., 2014). In the Appalachian Basin, thermogenic $\mathrm{CH}_{4}$ often migrates up from deeply 
buried shales with salty waters contaminated by Appalachian Basin brine (Christian et al., 2016; Harkness et al., 2017; Kreuzer et al., 2018; Llewellyn, 2014; Warner et al., 2012). This explains why some researchers have observed correlations between concentrations of $\mathrm{CH}_{4}$ and chloride $(\mathrm{Cl})$ in groundwater in PA and New York (Harkness et al., 2017; Kreuzer et al., 2018). Appalachian Basin brine salts may be observed in groundwater either because brine migration is ongoing today or because Appalachian Basin brine fluids trapped in small pores in aquifers are still being flushed out today (Llewellyn, 2014; Siegel et al., 2016, 2015b, 2015a; Warner et al., 2012).

Understanding the effect of $\mathrm{CH}_{4}$ leakage on water resources and its extent requires extensive measurements. Monitoring near oil and gas development has typically involved sampling private water wells. For example, most gas companies in PA now sample waters within at least 2,500 feet (760 m) before drilling (Siegel et al., 2015a). However, groundwater monitoring can be expensive, time-intensive, and difficult to accomplish in locations of public resistance. Additionally, $\mathrm{CH}_{4}$ sometimes migrates from shale gas wells far beyond distances of $760 \mathrm{~m}$ (Llewellyn et al., 2015; Reese et al., 2014; Woda et al., 2018). Even with extensive and time consuming collection of large datasets of groundwater chemistry (Wen et al., 2018), only relatively few sites of contamination are typically noted.

An alternate method of $\mathrm{CH}_{4}$ monitoring involves sampling stream waters (Grieve et al., 2018; Heilweil et al., 2013; Wendt et al., 2018). Methane in headwater streams is a useful indicator of subsurface contamination because streams collect groundwater from throughout a watershed as it flows upward toward the downstream outlet of the catchment, entraining dissolved or free-phase $\mathrm{CH}_{4}$ (Heilweil et al., 2015). Streams thus allow relatively rapid, low-cost sampling over large areas and can allow $\mathrm{CH}_{4}$ monitoring even in areas without homeowner water wells. Additionally, sampling of public streams can be extremely efficient as no homeowner permission is needed. 
Stream methane measurements have sometimes targeted specific sites (Grieve et al., 2018; Heilweil et al., 2015; Woda et al., 2018) and sometimes have been performed as a reconnaissance (Wendt et al., 2018). In the latter approach, researchers have collaborated with volunteer groups to improve efficiency, increase spatial density of sampling, increase access, or find contaminated sites only known to locals (Wendt et al., 2018). However, to determine if $\mathrm{CH}_{4}$ derives from anthropogenic or natural sources after reconnaissance monitoring requires further investigations. One common technique for such focused investigation is to analyze $\mathrm{CH}_{4}$ and $\mathrm{C}_{2} \mathrm{H}_{6}$ for stable isotope ratios (e.g., $\delta^{13} \mathrm{C}-\mathrm{CH}_{4}$ or $\delta^{13} \mathrm{C}-\mathrm{C}_{2} \mathrm{H}_{6}$ ). For example, values of $\delta^{13} \mathrm{C}-\mathrm{CH}_{4}<-60 \%$ generally characterize biogenic rather than thermogenic gas $\left(\delta^{13} \mathrm{C}_{-} \mathrm{CH}_{4}>-50 \%\right.$ ) (Révész et al., 2012). Investigations also must include geological reconnaissance to identify possible sources.

Like the observations for groundwater, $\left[\mathrm{CH}_{4}\right]$ in streams can derive from multiple sources. In relatively cool climates, $\left[\mathrm{CH}_{4}\right]$ values have been observed in headwater streams to range from $<0.06$ to $70 \mu \mathrm{g} / \mathrm{L}$ (de Angelis and Lilley, 1987; Jones and Mulholland, 1998; Stanley et al., 2016; Wendt et al., 2018). In PA, $\left[\mathrm{CH}_{4}\right]$ in stream waters are typically very low (i.e., at 131 sites the median was $\sim 1 \mu \mathrm{g} / \mathrm{L}$ ), and almost always higher than values in equilibrium with the atmosphere $(0.08 \mu \mathrm{g} / \mathrm{L})\left(\right.$ Wendt et al., 2018). Based on a compilation of $\left[\mathrm{CH}_{4}\right]$ in non-wetland streams in PA, a value of $0.5 \mu \mathrm{g} / \mathrm{L}$ was reported as the median for non-contaminated streams (i.e., background) and $4 \mu \mathrm{g} / \mathrm{L}$ was reported as a conservative threshold for sites that show evidence of potential contamination by gas from a non-natural origin (Wendt et al., 2018). Sites near putatively leaking shale gas wells and older oil/gas wells and near a landfill sometimes had $\left[\mathrm{CH}_{4}\right]$ values above the threshold (Wendt et al., 2018).

In this study, we extended the work of Wendt et al. (2018) by continuing to analyze streams for $\left[\mathrm{CH}_{4}\right]$ in the northern Appalachian Basin focusing on PA. We also analyzed groundwater 
discharges (seeps) where they appeared to be similar to observations of groundwater discharges near putatively leaking shale gas well(s) in central PA (Woda et al., 2018). Our intent was to test the hypothesis that streams are most contaminated by $\mathrm{CH}_{4}$ in the region with the longest history of hydrocarbon extraction activities.

\section{Methods}

\section{Sampling Design}

Results in this paper add to a previously published dataset of stream methane concentrations, $\left[\mathrm{CH}_{4}\right]$, measured in samples from the hydrocarbon-rich northern Appalachian Basin (Wendt et al., 2018). In particular, we present data for 378 new sites that were chosen and sampled based on the same criteria described by Wendt et al. (2018). We recognized that sites of fugitive methane contamination are rare in the Appalachian Basin (Brantley et al., 2014; Wen et al., 2019, 2018) and so we targeted sites suspected of contamination rather than choosing a statistically random set of sites. We "targeted" sites by selecting areas where we had information related to possible contamination into relatively low-flow streams. Like Wendt et al. (2018), we occasionally collaborated with watershed groups for sampling. This allowed us to get access to private land and to find locally known contamination sites. In addition, it led to a subset of samples from streams with wild trout populations. Efforts to reduce error with respect to volunteer sampling were described by Wendt et al. (2018). Although we recognized that wetlands can also be impacted by fugitive methane, we avoided wetland sites where we knew that natural sources of methane are prevalent (we lacked the resources to complete extensive isotopic measurements to distinguish biogenic from thermogenic $\mathrm{C}$ sources). 
Samples were collected mostly during warmer periods between February and November. We made no attempt to control the time of year of sampling although seasonality in $\left[\mathrm{CH}_{4}\right]$ in streams has been observed (Woda et al., 2018).

To test our hypothesis, our sampling targeted streams in three regions of the Basin. Regions were characterized by i) heavy development of wells in unconventional reservoirs (i.e., northern PA excluding Allegheny National Forest), ii) some of the oldest known development of oil and gas reservoirs in the USA (Ross, 1996), i.e. the Allegheny National Forest, where conventional oil and gas development is ongoing today,and iii) extensive development of conventional oil / gas + unconventional (shale) gas + coal mining (i.e., southwestern PA).

Our specific hypothesis was that $\left[\mathrm{CH}_{4}\right]$ in streams would be highest in region (ii), where oil and gas extraction is not only current today but has extended over the longest historical period. This seemed plausible because a gridded summary of $\mathrm{CH}_{4}$ emissions from oil and gas development for the three regions by the U.S. Environmental Protection Agency (Maasakkers et al., 2016) was calculated to be highest in region (ii). We furthermore reasoned that although $150 \mathrm{x}$ more $\mathrm{CH}_{4}$ is estimated to emit from coal mining activities in the SW PA region (iii) compared to oil and gas activities (Maasakkers et al., 2016), such coal-related emissions are dominated by releases from safety vents and methane drainage systems directly to the atmosphere (Kirchgessner et al., 2000).

Previous research in PA had also identified $\mathrm{CH}_{4}$-rich groundwater seeps near putatively leaking gas wells (Woda et al., 2018) (see Figure S1 and S2). (Groundwater seeps are defined as waters that are observed to upwell out of the subsurface, generally flowing downgradient into streams or lakes.) We therefore also sought to find and sample such seeps, especially when located in areas of oil/gas wells and associated with characteristics such as those reported by Woda et al. (2018): orange-colored sediments, bubbling, and/or evidence of microbial growth in associated 
mats or films. As the study progressed, we began sampling any seep with those characteristics or if they were associated with an odor of $\mathrm{H}_{2} \mathrm{~S}$, or the presence of oil, or proximity to hydrocarbon well infrastructure such as metal casings (Figure S3). Locations of seepages (Figure S4) were often learned from local volunteers or from online information (Burrows et al., 2015; PA DEP, 2018b).

Overall, hydrocarbon-rich waters from 21 springs and 8 discharging abandoned hydrocarbon wells were discovered. In addition, one volunteer's discovery that methane-rich waters were emitting from abandoned coal mine discharge led to the targeted sampling and analysis of $\left[\mathrm{CH}_{4}\right]$ in 14 abandoned mine discharges.

\section{Sample Collection}

For all waters, samples were returned quickly to the laboratory where they were refrigerated until analysis within 5 days of collection. Waters were sampled in one of three ways. In the first method, bottles were mailed to volunteers who sampled and express mailed the bottles back to the laboratory for analysis within 5 days. In the second method, samples were collected over a region by 20-40 volunteers in events organized by a volunteer group (Trout Unlimited). Five such "snapshot days" were conducted: in Pine Creek watershed, PA; in Monongahela National Forest, WV; and three in Allegheny National Forest, PA. Finally, in the third method of sampling, the authors sampled streams. Some of these samplings were return visits to sites where $\left[\mathrm{CH}_{4}\right]>4$ $\mu \mathrm{g} / \mathrm{L}$.

When possible, streams or groundwater discharges were sampled mid-flow as described previously (Grieve et al., 2018; Wendt et al., 2018; Woda et al., 2018). Bottles were stream-rinsed three times, filled and capped underwater without bubbles (when possible). For safety reasons, biocide was almost never used, either by volunteers or, to maintain consistency, scientists. A few 
samples reported here were collected by scientists working for the Susquehanna River Basin Commission into a smaller amber glass sampling bottle using a peristaltic pump and were preserved with $\mathrm{KOH}$. The use of a similar peristaltic pump was not observed to alter $\left[\mathrm{CH}_{4}\right]$ in PA streams compared to hand-sampled waters (Grieve, 2014). Similarly, the use of biocide showed no effects on stream $\left[\mathrm{CH}_{4}\right]$, as long as the methane was analyzed within 5 days (Grieve, 2014; Wendt et al., 2018). However, because we were unsure if the lack of biocide was problematic when sampling groundwaters in springs, $\mathrm{KOH}$ pellets were used as a biocide for a few test seeps.

When sites were revisited and resampled, waters were analyzed for $\left[\mathrm{CH}_{4}\right]$, and, occasionally, $\left[\mathrm{C}_{2} \mathrm{H}_{6}\right]$ and hydrocarbon isotopes. When possible, field parameters were measured ( $\mathrm{pH}$, oxidation reduction potential, temperature, specific conductivity (SPC), and dissolved oxygen (DO)) using a YSI Professional Plus meter, calibrated before each trip as previously described (Woda et al., 2018). Where possible, sites with high $\left[\mathrm{CH}_{4}\right]$ were investigated for possible hydrocarbon sources and waters were collected for inorganic solute analyses. Those samples were filtered using a prerinsed $0.45 \mu \mathrm{m}$ filter. Samples for cation analysis were additionally acidified using trace metal grade pure nitric acid before transporting in a cooler.

\section{Laboratory Methods}

Methods for analysis of hydrocarbons, hydrocarbon isotopes, and inorganic solutes were described previously (Woda et al., 2018). Reproducibility of measured $\left[\mathrm{CH}_{4}\right]$ in a stream over a short time interval is larger than the laboratory analytical precision: reproducibility of $\pm 12 \%$ is expected for low-flow stream concentrations (Woda et al., 2018).

$\delta^{13} \mathrm{C}_{-} \mathrm{CH}_{4}$ values were analyzed for some samples with $\left[\mathrm{CH}_{4}\right]>2 \mu \mathrm{g} / \mathrm{L}$ at the Laboratory for Metals and Isotopes in the Environment, Pennsylvania State University or the University of 
Arkansas Stable Isotope Laboratory. Major cation concentrations were measured for some samples with a Perkin-Elmer Optima 5300 inductively coupled plasma atomic emission spectrophotometer (ICP-AES). For a few samples, a Thermo Fisher Scientific X Series 2 Inductively Coupled Plasma Mass Spectrometer (ICP-MS) with Collision Cell Technology was used to analyze chromium (Cr), arsenic (As), and uranium (U). A Dionex ICS 2500 ion chromatograph (IC) was used to analyze major anions.

\section{Results}

\section{All Stream Samples}

We present analyses from 43 groundwater discharge sites, and 378 stream sites (SI Tables S1S10) sampled in PA and West Virginia, 20 of which were collected by Susquehanna River Basin Commission. Of the stream sites, 127 were located in the Allegheny National Forest, the area closest to the oldest oil well in the USA. The stream analyses were compiled with data for 151 other stream sites from PA and New York that had been reported previously using similar or identical techniques (Grieve et al., 2018; Heilweil et al., 2015, 2014; Wendt et al., 2018; Woda et al., 2018). The result is a stream database of 1,077 samples at 529 sites in PA, WV, and NY. The majority of sites are in PA (Figure 2). When multiple samples were collected at the same site, the site-aggregated mean $\left[\mathrm{CH}_{4}\right]$ is reported (Table S10). 


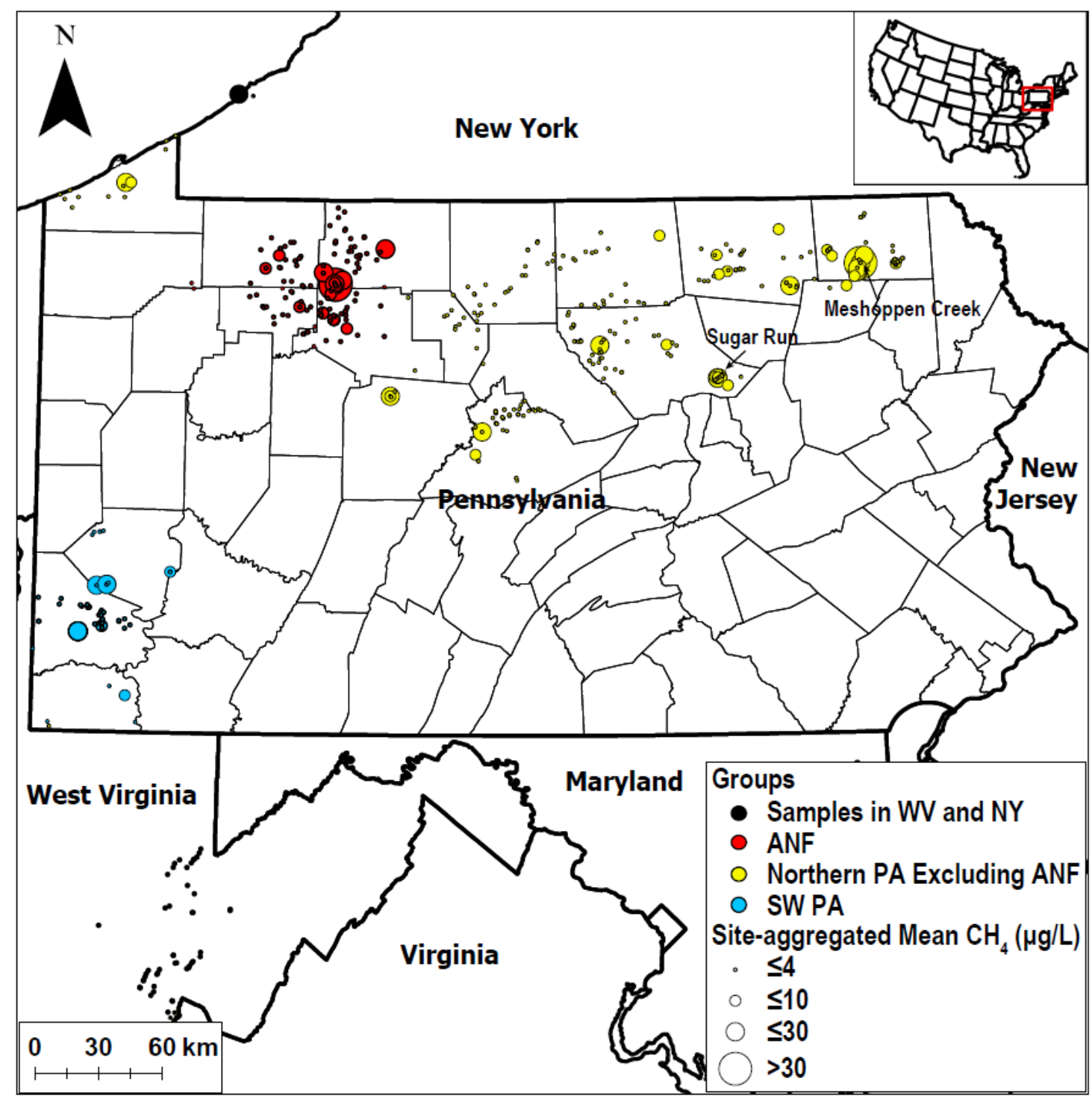

Figure 2: Site-aggregated mean values of $\left[\mathrm{CH}_{4}\right]$ measured at 529 stream sites where increasing symbol sizes correspond with increasing $\left[\mathrm{CH}_{4}\right]$. Some of the data were previously reported as indicated in main text. Samples sites were grouped into four subsets as shown by colors: sites that are (1) outside of PA, (2) in Allegheny National Forest (ANF), close to one of the locations of some of the oldest and most densely drilled conventional oil and gas wells in the USA, (3) northern PA outside of the Allegheny National Forest (ANF) in a location with an extremely high density of new unconventional (shale gas) wells; and (4) southwestern (SW) PA, the location with an extremely high density of coal mines, conventional oil/gas, and shale gas wells.

$\left[\mathrm{CH}_{4}\right]$ measured in the 1,077 individual stream samples ranged from less than the detection $\operatorname{limit}(0.06 \mu \mathrm{g} / \mathrm{L})$ to $76.6 \mu \mathrm{g} / \mathrm{L}$ with the mean $=3.4 \mu \mathrm{g} / \mathrm{L}$ and median $=1.1 \mu \mathrm{g} / \mathrm{L}$. Figure S5 shows that the mean of the 529 site-aggregated means was also higher $(2.5 \mu \mathrm{g} / \mathrm{L})$ than the median $(0.9$ 
$\mu \mathrm{g} / \mathrm{L}$ ). Analyses for $\delta^{13} \mathrm{C}-\mathrm{CH}_{4}$ for 95 stream samples targeted for focused investigation ranged from $-61.4 \%$ to $-11.4 \%$, with the mean $=-39 \%$ and the median $=-40 \%$.

\section{High Methane Stream Samples}

Following Wendt et al. (2018), sites with site-aggregated mean $\left[\mathrm{CH}_{4}\right]<4.0 \mu \mathrm{g} / \mathrm{L}$ were generally not investigated further. In total, 75 out of 529 sites (14\%) from 35 streams revealed siteaggregated means $>4 \mu \mathrm{g} / \mathrm{L}$ (Figure 3). Of these sites, 45 (25 streams) were newly sampled in this study, 28 (10 streams) were reported previously (Grieve et al., 2018; Heilweil et al., 2015; Wendt et al., 2018), and 2 (2 streams) were sampled solely by the Susquehanna River Basin Coalition. The distribution of site-aggregated means for these high-methane samples is right-skewed (i.e., mean $>$ median) (Figure 3).

In the region with the oldest oil and gas wells (the Allegheny National Forest), the siteaggregated mean $\left[\mathrm{CH}_{4}\right]$ values for 21 non-wetland stream sites were larger than $4 \mu \mathrm{g} / \mathrm{L}$, the threshold value indicating potential $\mathrm{CH}_{4}$ leakage for a non-wetland site (Wendt et al., 2018). Of the 14 sites where $\delta^{13} \mathrm{C}-\mathrm{CH}_{4}$ were analyzed in these samples, 6 had $\delta^{13} \mathrm{C}-\mathrm{CH}_{4}$ values $>-50 \%$ and three had detectable ethane (Table S10). Such $\delta^{13} \mathrm{C}_{-} \mathrm{CH}_{4}$ values and the presence of ethane are consistent with emissions of thermogenic gas at these sites (Révész et al., 2012; Schoell, 1980).

Of the 12 stream sites with $\left[\mathrm{CH}_{4}\right]>4 \mu \mathrm{g} / \mathrm{L}$ that we sampled in the region of SW PA with conventional oil/gas + shale gas + coal mining, nine were within proximity of a coal mine and were thus considered likely to contain $\mathrm{CH}_{4}$ derived from the coal. Samples of drainage from abandoned mine drainage (AMD) throughout the state showed values of $\left[\mathrm{CH}_{4}\right]>20 \mu \mathrm{g} / \mathrm{L}$ and usually $>100 \mu \mathrm{g} / \mathrm{L}\left(\right.$ mean $\left[\mathrm{CH}_{4}\right]=141 \mu \mathrm{g} / \mathrm{L}$, median $\left.=108 \mu \mathrm{g} / \mathrm{L}\right)$. For example, Coal Run is a stream near Pittsburgh PA impacted by an AMD seep with $\left[\mathrm{CH}_{4}\right]$ values as high as $149 \mu \mathrm{g} / \mathrm{L}$. 


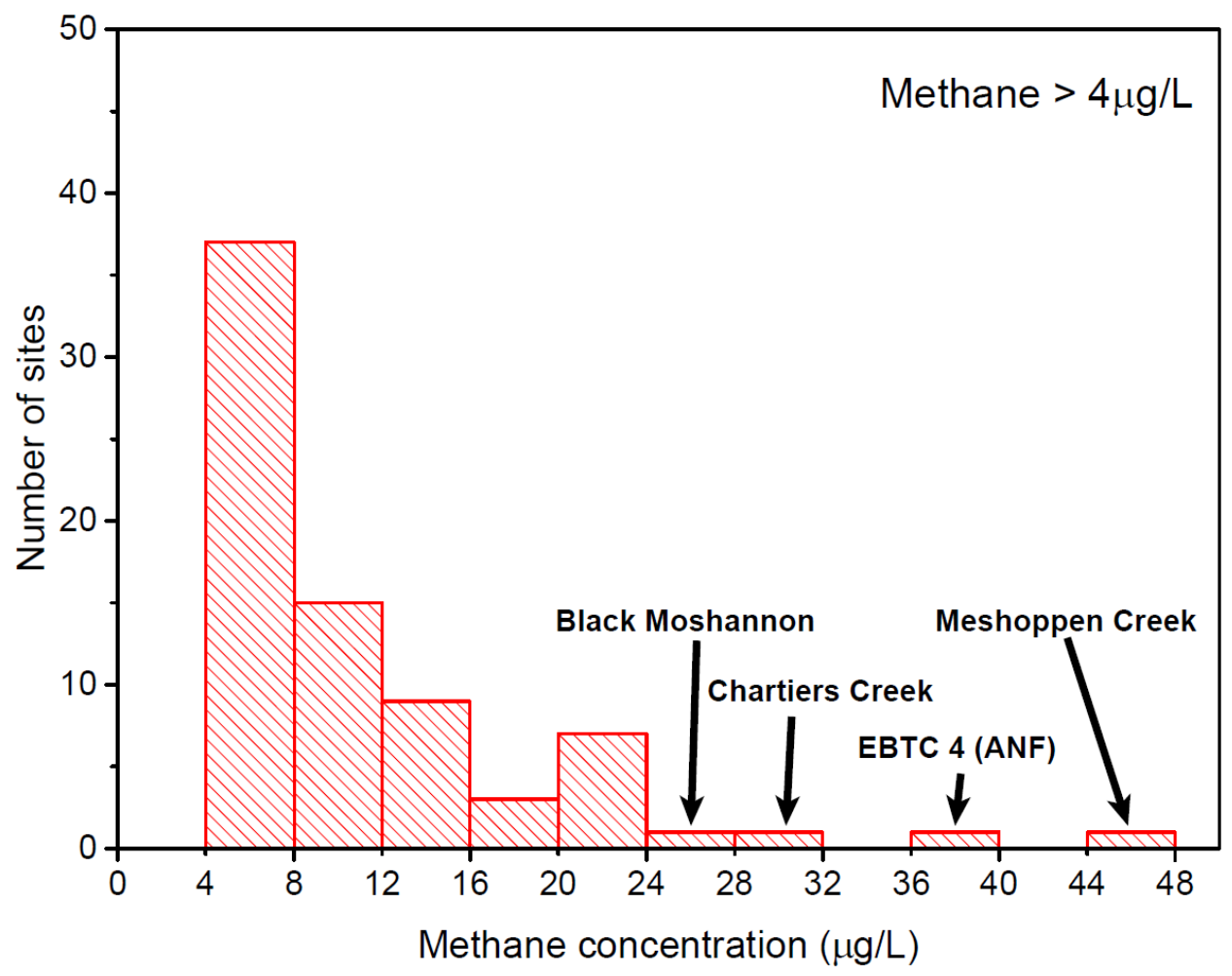

Figure 3: Histogram of the 75 site-aggregated mean concentrations for stream sites with methane $>4 \mu \mathrm{g} / \mathrm{L}$. EBTC stands for East Branch Tionesta Creek site in the Allegheny National Forest (ANF). Black Moshannon is a natural wetland lake sampled for comparison (Wendt et al., 2018), Chartiers Creek is located in SW PA, and Meshoppen Creek is located near an area of heavy shale gas development in northeastern PA near Dimock.

\section{Groundwater Discharge Samples}

Groundwater discharges were sampled at 43 locations (124 samples). Sites were selected because of one or more of the following: they i) were lined with orange sediments, ii) were characterized by microbial growth in mats or films (e.g. Figure S2), iii) seeped oil, iv) smelled of $\mathrm{H}_{2} \mathrm{~S}$, v) leaked directly from metal well casings, iv) were located near putatively leaking oil or gas wells, or vii) were reported as AMD in the literature. A few sites were sampled previously (Grieve et al., 2018; Heilweil et al., 2015; Kang et al., 2014; Woda et al., 2018). One additional discharge sampled for comparison was Salt Springs, a natural seep in northern PA that has been documented to contain Appalachian Basin brines salts and methane (the spring has now been modified with 
drilling and a pipe so is no longer completely natural). Statistics for some parameters are summarized in Table 1 (see also the full set of parameters in Table S11).

Values of $\left[\mathrm{CH}_{4}\right]$ sometimes varied by more than $60 \%$ in groundwater seeps collected at the same spot and time with and without $\mathrm{KOH}$. These $\mathrm{KOH}$-preserved seep samples were systematically higher than non-preserved samples (Table S4). This variability is attributed to the likely presence of methane-oxidizing bacteria in the aquifers that continued to metabolize methane in the bottle between sampling and analysis ( $<5$ days). Consistent with this, when a discrepancy was observed, samples without $\mathrm{KOH}$ revealed less negative $\delta^{13} \mathrm{C}-\mathrm{CH}_{4}$ values as compared to those with $\mathrm{KOH}$ (Tables S1, S4).

Almost all 43 seeps revealed elevated $\left[\mathrm{CH}_{4}\right]$ and $\left[\mathrm{C}_{2} \mathrm{H}_{6}\right]$ (when it was measured). Values of site aggregated mean $\left[\mathrm{CH}_{4}\right]$, ranging from $120-9,500 \mu \mathrm{g} / \mathrm{L}$, were much higher than values in stream samples. In the discussion below, we first discuss abandoned mine drainage (AMD) seeps (14 sites), then seeps leaking from abandoned wells ( 8 sites), and then the remaining seeps ( 21 sites). These 21 were all sampled further than $1.2 \mathrm{~km}$ from a coal mine.

The 14 AMD sites were identified because they were located within direct proximity of a known coal mine (Figure S6) or because they were described as AMD previously (Cravotta, 2008; Burrows et al., 2015; PA DEP, 2018a). A compilation of 144 previously measured AMD samples (Cravotta, 2008) was incorporated into Tables 1 and S11 for comparison to the AMD samples collected in this study. Concentrations of metals, calcium, magnesium, and sulfate were higher than in the other discharges except Salt Springs (Table S11). Values of $\left[\mathrm{CH}_{4}\right]$ were lower $($ Table 1). $\left[\mathrm{CH}_{4}\right]$ measured in individual samples collected directly from discharges of AMD ( $\mathrm{n}=30$ samples from 14 sites) ranged from 49.8 to $549 \mu \mathrm{g} / \mathrm{L}$. $\delta^{13} \mathrm{C}-\mathrm{CH}_{4}$ values were measured at two 
AMD sites (Gladden discharge and Blythdale discharge (Vesper et al., 2016)): $-31.0 \%$ and 43.0\%, respectively (Table S7).

Eight samples were collected from leaking abandoned wells, often from water pooled around or flowing out of casings that showed active bubbling. One site (labelled ANF Leaking Well 5) was previously investigated by Kang et al. (2014) for atmospheric $\mathrm{CH}_{4}$ flux. These samples showed the highest concentrations of methane, ethane, chloride, barium, and bromide and the lowest metal concentrations (Tables S1-S3, Figure S4). They also typically showed $[\mathrm{Ca}] /[\mathrm{Na}]$ ratios similar to Appalachian Basin brine (Figure 4). Arsenic concentrations (10.5 and $19.2 \mu \mathrm{g} / \mathrm{L}$ ) were above USA Environmental Protection Agency (US EPA) drinking water standards (Table S3) at two leaking abandoned wells.

The remaining 21 groundwater seeps were neither AMD nor leaking abandoned well water, but all showed high $\left[\mathrm{CH}_{4}\right]($ mean $=1.85 \mathrm{mg} / \mathrm{L}$, median $=0.76 \mathrm{mg} / \mathrm{L})$. None of these seeps were closer than $1.2 \mathrm{~km}$ to a known coal mine or mine discharge. Tables 1 and $\mathrm{S} 11$ and Figure 4 show that the maximum sulfate concentrations in these 21 discharges were lower than the minimum sulfate concentration in all the collated AMD samples. They were also generally lower in calcium, magnesium, and other metal concentrations and higher in methane (and sometimes ethane) concentrations than AMD (Table S11). Although all of these samples are thought to be GLD, to be as conservative as possible, 11 of these 21 are labelled in Figure 4 and Table 1 and S11 as "ambiguous GLD" because they were located within $2 \mathrm{~km}$ of a coal mine. 


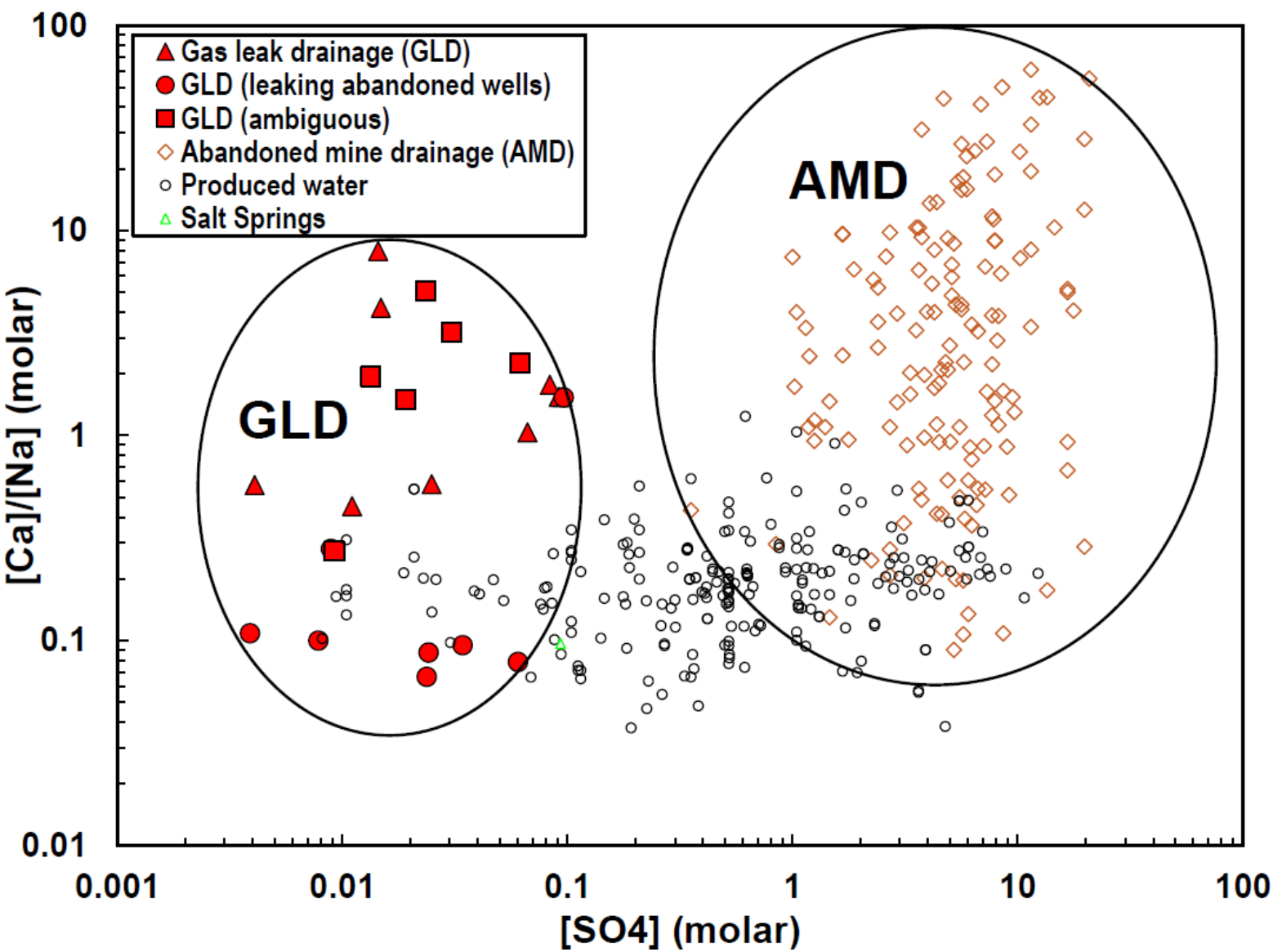

Figure 4: A plot of $[\mathrm{Ca}] /[\mathrm{Na}]$ vs $\left[\mathrm{SO}_{4}\right]$ for different types of waters: abandoned mine drainage (AMD) are shown as diamonds (this study; Hedin et al. (2005); Cravotta (2008)), produced waters from conventional and unconventional oil and gas wells are shown as black circles (USGS Produced Waters Database: https://www2.usgs.gov/science/cite-view.php?cite=1259), and gas leak drainage (GLD) is shown as red symbols. Waters sampled directly from leaking abandoned wells, a subset of GLD shown as circles, often contain brine salts in ratios similar to Appalachian Basin brine. Red squares are suspected GLD but are located within $2 \mathrm{~km}$ of a coal mine and are thus labelled "ambiguous" in source.

\section{Discussion}

\section{Stream Methane}

Data presented here and reviewed in Wendt et al. (2018) for non-wetland waters include 75 site-aggregated mean $\left[\mathrm{CH}_{4}\right]$ values $>4 \mu \mathrm{g} / \mathrm{L}$. This value is the threshold indicator of potential contamination for non-wetland waters identified by Wendt et al. (2018) for the northern Appalachian Basin. Wetlands were avoided because very high concentrations $(\sim 26 \mu \mathrm{g} / \mathrm{L})$ can be recorded in PA wetlands (e.g., Black Moshannon, Table S10, Figure 3) and we lacked resources 
for adequate investigation of biogenic versus thermogenic gas. By not targeting wetlands, we obviously were unable to detect contamination in wetlands. One example of a wetland that may be contaminated by natural gas from leaking shale gas wells is in Meshoppen Creek, as discussed by Wendt et al. (2018). That site, located in Dimock where many problems with gas wells have been noted (Hammond et al., 2020), still retains a signal consistent with leakage from shale gas and is discussed briefly below.

Most of the 1,077 samples reported here were low in $\left[\mathrm{CH}_{4}\right]$, including nine with $\left[\mathrm{CH}_{4}\right] \leq 0.06$ $\mu \mathrm{g} / \mathrm{L}$ (the detection limit), i.e., lower than concentrations in equilibrium with today's atmosphere $(0.08 \mu \mathrm{g} / \mathrm{L})$. Such low concentrations document waters isolated from the atmosphere and from sediments with methanogenic micro-organisms.

Every non-wetland site that was measured to have $\left[\mathrm{CH}_{4}\right]>4 \mu \mathrm{g} / \mathrm{L}$ was a site previously suspected for contamination either from published reports or local volunteer knowledge. For example, the highest individual (not site-aggregated) values of $\left[\mathrm{CH}_{4}\right]$ for streams equaled 68.5 $\mu \mathrm{g} / \mathrm{L}$ in Meshoppen Creek (near Dimock, Susquehanna County; Table S10) and 76.6 $\mu \mathrm{g} / \mathrm{L}$ in Sugar Run (near Hughesville, Lycoming County), both of which are near sites of reported issues during shale-gas development (Osborn et al., 2011; Wendt et al., 2018; Woda et al., 2018). Thus, as pointed out by Grieve et al. (2018), stream sampling is better at narrowing in on contamination where it is already suspected rather than finding new leakages. This is because most streams have low $\left[\mathrm{CH}_{4}\right]$ even near contaminating sources because $\mathrm{CH}_{4}$ is quickly metabolized, lost to the atmosphere, and/or diluted.

\section{AMD and GLD}


All the groundwater discharges (also known as seeps, seepages, or springs) had high $\left[\mathrm{CH}_{4}\right]$, often more than orders of magnitude more concentrated than the streams. This is consistent with groundwater as a source of $\mathrm{CH}_{4}$ to streams in this Basin. About $1 / 4$ of these groundwater discharges were identified as AMD. The rest of the seeps (Tables S4-S6) visually and chemically resembled previously reported methane-rich seeps near Sugar Run (Lycoming County), PA in that they were characterized by red-stained precipitates and microbial biofilms (Figures S1 and S2). The Sugar Run seeps are putatively contaminated by gas leaking from one or more unconventional gas wells (Woda et al., 2018).

$\left[\mathrm{CH}_{4}\right]$ site aggregated mean values measured in the 27 seeps that were not AMD (Table 1) were sometimes extremely high, ranging from 0.11 to $23,000 \mu \mathrm{g} / \mathrm{L}$. Where ethane was analyzed, it ranged from 0.58 to $2,450 \mu \mathrm{g} / \mathrm{L}$ (Table S4) with molar concentration ratios of methane/ethane from 3 to 578 , and $\delta^{13} \mathrm{C}_{-}-\mathrm{CH}_{4}$ and $\delta^{13} \mathrm{C}_{-} \mathrm{C}_{2} \mathrm{H}_{6}$ from $37.6 \%$ to $-65.7 \%$ and $-28.2 \%$ to $-35.7 \%$ o respectively (Table S4). Sulfate concentrations were very low in GLD compared to AMD, but pH and barium concentrations tended to be higher (Table 1, Figure 4).

By analogy to AMD, we define a new term for this type of groundwater discharge: gas leak discharge (or drainage, GLD). GLD includes both waters contaminated by natural gas that has migrated upward within wellbores (leaking abandoned wells) or waters infiltrated by gas that has laterally migrated over 100 s to 1000 s of meters through fractures or aquifers. Based on data in Table 1, S6 and S11, the chemistry of GLD is characterized by elevated hydrocarbon concentrations (methane, ethane), low oxidation reduction potential $(<169 \mathrm{mV})$, higher $\mathrm{pH}$, and low sulfate concentrations $(<9.3 \mathrm{mg} / \mathrm{L})$. Carbon isotopes, when measured on $\mathrm{CH}_{4}$, were consistent with a thermogenic signature. For some of these discharges sampled in the Allegheny National 
Forest, methane/ethane ratios were below 10, consistent with an oil rather than gas source (Jones and Drozd, 1979).

As shown in Figure 4, GLD waters are chemically distinct from AMD. Figure 4 also shows data for samples of Appalachian Basin brine reported in the USGS produced waters database (https://www2.usgs.gov/science/cite-view.php?cite=1259) for conventional and unconventional oil and gas wells in PA ( $n=226)$. GLD waters sampled from leaking abandoned wells often have low $[\mathrm{Ca}] /[\mathrm{Na}]$ like those observed in Appalachian Basin brine. Some of the GLD show higher $[\mathrm{Ca}] /[\mathrm{Na}]$ ratios that are similar to shallow recharge in PA (e.g., Siegel et al., 2015b; Molofsky et al., 2016).

\section{Leaking Abandoned Well Waters}

Although waters from leaking abandoned wells are considered a subset of GLD, we observed these waters could have a distinct chemistry; for example, many plot in the field of Appalachian Basin brine affected waters (Figure 4). GLD waters that were not sampled directly from abandoned well casings generally show higher metal concentrations (Fe, Mn, As), lower specific conductivity (50-424 $\mu \mathrm{S} / \mathrm{cm})$, slightly acidic to neutral $\mathrm{pH}$ (5.8-7.08), and lower chloride concentrations (Table S4-S6) compared to waters sampled directly from leaking abandoned wells (they are generally not as metal-rich and have slightly higher $\mathrm{pH}$ values (6-8.3) and lower sulfate concentrations (Tables S1-S6)). Often waters from abandoned wells smell of $\mathrm{H}_{2} \mathrm{~S}$ while it was rare to smell $\mathrm{H}_{2} \mathrm{~S}$ at any of the non-leaking abandoned well GLDs.

Several ideas could explain these differences in chemistry. First, many of the leaking abandoned wells were sampled in the Allegheny National Forest in northeastern PA: the difference in $[\mathrm{Ca}] /[\mathrm{Na}]$ shown in Figure 4 may indicate that Appalachian Basin brine salts are entrained in 
those waters because the depth to brine is shallower in that part of PA (Brantley et al., 2014). To explain the differences in metal and sulfur concentrations (see also, Wen et al. (2019)) we explored aspects of chemical equilibria for the GLD waters using Geochemist's Workbench (GWB, version 9.0 and thermo.dat).

Two of the GLD samples analyzed with GWB were not sampled at a leaking abandoned well (Seep 1.6 from Sugar Run and Ludlow Seepage from Sheffield PA) while two were sampled directly from abandoned wells (ANF wells 1 and 5). The analyzed [ $\left.\mathrm{CH}_{4}\right]$ ranged from 4 to $23 \mathrm{mg} / \mathrm{L}$ and $\left[\mathrm{SO}_{4}\right]$ ranged from 1.4 to $5.8 \mathrm{mg} / \mathrm{L}$. For every sample, chemical equilibrium was calculated to result in $\left[\mathrm{SO}_{4}\right]$ values that were many orders of magnitude lower than observed because of the potential for sulfate reduction by $\mathrm{CH}_{4}$ followed by precipitation of sulfide as pyrite. For the waters not sampled at abandoned wells, ferrous iron remained in solution after precipitation of pyrite, but no $\mathrm{S}$ species remained. In contrast, in the leaking abandoned well waters, reduction of sulfate and precipitation of pyrite did not remove all the aqueous sulfur: $\mathrm{HS}^{-}$remained in solution at concentrations from 0.1 to $0.7 \mathrm{mg} / \mathrm{L}$ while iron was depleted to immeasurably low concentration.

Given these observations, the difference between metal-rich (non-leaking abandoned well) GLD and $\mathrm{H}_{2} \mathrm{~S}$-rich leaking abandoned well waters is attributed to the different Fe to $\mathrm{S}$ ratios. For waters that start initially with molar ratios of $[\mathrm{Fe}] /[\mathrm{S}]<0.5$, iron depletes in solution before sulfate depletes during precipitation of pyrite because of the stoichiometric ratio of $\mathrm{Fe}$ to $\mathrm{S}\left(\mathrm{FeS}_{2}\right)$. In this type of water from leaking abandoned wells, the water becomes metal-deficient and bisulfide-rich. The water chemistry is dominated by sulfur reduction, and this process drives $\mathrm{pH}$ up as it produces alkalinity. On the other hand, if $[\mathrm{Fe}] /[\mathrm{S}]$ is $>0.5$, then sulfate runs out before iron as pyrite precipitates: the water becomes metal-rich and bisulfide-deficient. Consistent with this, the 
$[\mathrm{Fe}] /[\mathrm{S}]$ ratios for the Ludlow seep (2.9) and Sugar Run 1.6 seep (1.7) are high compared to those for ANF Wells $1(0.009)$ and 5 (0.02).

We thus attribute some of the differences in water chemistry for these two types of GLD to iron limitation (leaking abandoned well waters) versus sulfur limitation (other GLD waters). Perhaps the rock around well casings becomes a halo depleted in reactive Fe(III) oxides after decades of focused $\mathrm{CH}_{4}$ flux upward around the borehole. At the same time, sulfur can continuously enter the system from rain or sulfur-rich brines (e.g., Dresel and Rose, 2010; Haluszczak et al., 2013), but Fe becomes depleted. In contrast, GLD waters that do not emit directly from a wellbore become limited in $\mathrm{S}$ compared to Fe because reduction of Fe(III) oxides along their long, lateral flowpath continues to release $\mathrm{Fe}(\mathrm{II})$ to solution faster than $\mathrm{S}$ enters the system from rain. In this case $[\mathrm{Fe}] /[\mathrm{S}]>0.5$ and the waters become iron-rich and sulfur-depleted.

\section{Methane in Areas of Oil, Gas, and Coal}

We hypothesized that streams are most contaminated by $\mathrm{CH}_{4}$ in the region with the longest history of hydrocarbon extraction activities. We specifically explored this hypothesis by looking at stream sites $(\mathrm{n}=476)$ in PA from three regions: Allegheny National Forest in northwestern PA $(n=127)$, northern PA outside the Allegheny National Forest $(n=287)$, and southwestern PA (SW PA, n=62) (Figure 2). As shown in Figure 1, these three regions can also be characterized by the various type of hydrocarbon extraction: northwestern PA is dominated by oil and gas wells in conventional reservoirs with very few shale gas wells, northern PA encompasses one of the two hotspots for drilling of shale gas wells (Bradford County) and only a few conventional oil and gas

wells, and southwestern PA encompasses the other shale gas hotspot as well as a high density of oil/gas wells in conventional reservoirs as well as coal mines. The Allegheny National Forest also 
overlies hydrocarbon reservoirs that are very shallow and have the longest history of extraction (Ross, 1996; Schimmelmann et al., 2018; Siegel et al., 2015a).

Median values of $\left[\mathrm{CH}_{4}\right]$ for the three groups $(1,0.7$, and $2.4 \mu \mathrm{g} / \mathrm{L}$ respectively) were compared using a Wilcox test. Contradicting our hypothesis, the first two groups, Allegheny National Forest and northern PA outside of Allegheny National Forest, were not statistically different: only the median $\left[\mathrm{CH}_{4}\right]$ for SW PA is statistically different (higher) than that of the other two regions. A comparison of Figures 1 and 2 shows that only the SW PA region is the locus of a high density of coal mines as well as the locus of a relatively high density of all three hydrocarbon extraction types together (conventional and unconventional oil / gas, coal mining). We therefore concluded that streams do not show statistically higher $\left[\mathrm{CH}_{4}\right]$ where oil / gas wells are oldest but rather in the region with the longest history and/or highest density of coal mining.

Methane is presumably found in streams near coal mines because $\mathrm{CH}_{4}$, formed in coalbeds either thermogenically or biogenically, is held by sorption to fracture walls (or cleats) and is released during mining and disturbance (U. S. National Research Council, 2010). The effect of mining on $\mathrm{CH}_{4}$ release may be especially important in SW PA because of the co-location of oil and gas development. In that area, Barkley et al. (2019) showed that atmospheric emissions of $\mathrm{CH}_{4}$ from coal mining activity was more than twice as large as the flux attributed to development of shale gas (see their Table S1). For abandoned oil and gas wells in coal areas in PA, Kang et al. (2017) measured methane emission fluxes and reported that some wells that were plugged but vented for safety emitted the most $\mathrm{CH}_{4}$. Townsend-Small et al. (2016) also noted that the source of $\mathrm{CH}_{4}$ in old gas wells in Ohio sometimes derived partly from coal bed methane. 


\section{Atmospheric Methane Fluxes from Coal Mines}

Direct emissions of $\mathrm{CH}_{4}$ to the atmosphere from coal mines (such as those measured by Barkley et al. (2019) in SW PA) is a large $\mathrm{CH}_{4}$ flux in PA where at least 5,000 abandoned, orphaned, or operating coal mines are located (PA DEP, 2018a). Underground coal mines are the largest source of this gas emission because they are intentionally vented to the atmosphere to avoid dangerous $\mathrm{CH}_{4}$ buildup (Kirchgessner et al., 2000). These vented atmospheric emissions generally dominate the total emissions from coal mines. The $20-48 \%$ of coal mines in the Appalachian Basin that are flooded are generally thought to release $\mathrm{CH}_{4}$ in the first $\sim 15$ years after flooding (Cote et al., 2004; Krause and Pokryszka, 2013). However, water discharging from flooded abandoned mine openings, fractures, or wells can still degas $\mathrm{CH}_{4}$ to the atmosphere (Burrows et al., 2015; Hedin et al., 2005). For example, we measured [ $\left.\mathrm{CH}_{4}\right]$ in one AMD discharge (Gladden, Tables S7S9) that dropped from $199 \mu \mathrm{g} / \mathrm{L}$ to $<20 \mu \mathrm{g} / \mathrm{L}$ over a distance of $191 \mathrm{~m}$ after tumbling over a large waterfall (Figures S7, S8).

Our measurements on AMD here can be used to estimate the flux of $\mathrm{CH}_{4}$ from flooded coal mines in the study areas. Flow rates are available (Burrows et al., 2015; PA DEP, 2018a) for discharges from ten abandoned coal mines where we measured $\left[\mathrm{CH}_{4}\right]$ (Table S7). The calculation of flow rate $\mathrm{x}\left[\mathrm{CH}_{4}\right]$ yields a total flux for the ten mines of $\sim 16,000 \mathrm{~kg} \mathrm{CH}_{4} \mathrm{y}^{-1}$ or $\sim 1,600 \mathrm{~kg} \mathrm{CH}_{4}$ $\mathrm{y}^{-1}$ per mine. This value is about $20 \times$ more than the approximate $\mathrm{CH}_{4}$ flux measured in PA and Ohio per abandoned oil/gas well, $100 \mathrm{~kg} \mathrm{y}^{-1}$ (Kang et al., 2014; Townsend-Small et al., 2016). Statewide, 323 coal mines are identified to be discharging $5.25 \times 10^{5} \mathrm{GPM}\left(10^{12} \mathrm{~L} \mathrm{y}^{-1}\right)(\mathrm{PA}$ DEP, 2018a). Multiplying our flux per mine of $1,600 \mathrm{~kg} \mathrm{CH}_{4} \mathrm{y}^{-1}$ by 323 yields $5.2 \times 10^{5} \mathrm{~kg} \mathrm{CH}_{4} \mathrm{y}^{-1}$ statewide. Alternately, multiplying the state-reported total discharge from flooded mines of $10^{12} \mathrm{~L}$ $\mathrm{y}^{-1}$ by the mean $\left[\mathrm{CH}_{4}\right]$ of $141 \mu \mathrm{g} / \mathrm{L}$ for the discharges we measured (Table S7) yields a total flux 


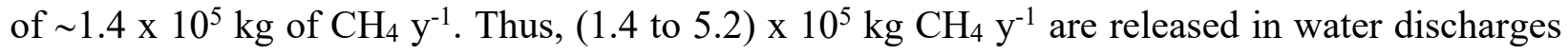
and ultimately to the atmosphere.

Although this $\mathrm{CH}_{4}$ flux from flooded abandoned mines sounds large, it is small compared to other fluxes from hydrocarbon extraction in the state. For example, the abandoned oil and gas

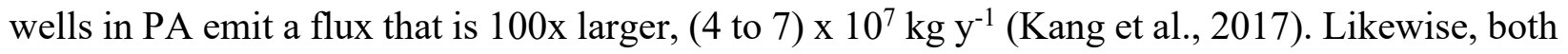
the leak rate for $\mathrm{CH}_{4}$ from all producing conventional and unconventional gas wells in PA, $7.26 \mathrm{x}$ $10^{8} \mathrm{~kg} \mathrm{CH}_{4} \mathrm{y}^{-1}$ (Omara et al., 2016), and the $\mathrm{CH}_{4}$ emission rate from all coal mine-related activities from the US EPA gridded estimate integrated over our three study areas in PA (Maasakkers et al., 2016), $4.81 \times 10^{8} \mathrm{~kg} \mathrm{y}^{-1}$, are 1000x larger than the flooded mine estimate.

\section{Conclusion}

We investigated the streams and groundwater seeps in the northern Appalachian Basin to test the hypothesis that $\mathrm{CH}_{4}$ concentrations in streams might be highest in regions with long records of past and present oil and gas extraction. We reported $\mathrm{CH}_{4}$ concentrations $\left(\left[\mathrm{CH}_{4}\right]\right)$ in streams at 529 sites, mostly in Pennsylvania. Most concentrations were very low, and some were below the value for equilibrium with the atmosphere. In non-wetland streams, $\left[\mathrm{CH}_{4}\right]$ was higher than a threshold value indicating potential contamination in 75 sites. The distribution of concentrations was rightskewed with a large number of low-concentration streams. The median of $\left[\mathrm{CH}_{4}\right]$ values in the subregion with the oldest oil and gas wells was not statistically different from the median of the region with one of the two hotspots of shale gas wells in the state. On the other hand, the median of $\left[\mathrm{CH}_{4}\right]$ values in streams was statistically highest in the southwestern part of the state. High stream contamination was attributed in that sub-region mainly to the high density of coal mines, but 
perhaps also to the co-location of all three hydrocarbon extraction industries together (oil, gas, coal).

While investigating streams we observed that some streams receive high- $\left[\mathrm{CH}_{4}\right]$ groundwaters from abandoned mine drainage (AMD). Other streams were contaminated from high- $\left[\mathrm{CH}_{4}\right]$ groundwaters that were sampled more than $1.2 \mathrm{~km}$ from coal mines and showed lower concentrations of dissolved sulfate and metals than AMD. These seeps were often associated with old oil/gas wells and recent shale gas wells. We introduced a new term, "gas leak discharge" (GLD). GLD looks like AMD when visually inspected in the field but is related to oil and gas development rather than coal mining. As shale gas wells proliferate around the world, GLD may become more and more important, just as AMD is important worldwide in coal mined regions. 


\section{Acknowledgments}

Funding for S.L.B., J.W., and T.W. was derived from grant IIS-16-39150 to S.L.B. and Zhenhui Li from the National Science Foundation. T.W. was also supported by the College of Earth and Mineral Sciences Dean's Fund for Postdoc-Facilitated Innovation at the Penn State University. We acknowledge all organizations that helped collect data and provide information including Trout Unlimited, Pitt-Bradford University, Susquehanna River Basin Commission, McKean County Conservation district, Elk County Conservation District Chartiers Creek Watershed Association, Centre County Senior Citizen Environmental Corp, West Virginia Rivers Coalition, Western Pennsylvania Conservancy, The US Forest Service, The Centre County Pennsylvania Senior Environmental Corps, QV Creeks from Fern Hollow Nature Center, Warren County Conservation

District and Penn State TeenShale Network. Discussions with A. Wendt are also acknowledged. 


\section{Table 1. Water chemistry of GLD and AMD (site aggregated)}

\begin{tabular}{|c|c|c|c|c|c|c|}
\hline Methane (CH4) - $\mu \mathrm{g} / \mathrm{L}$ & number of sites & Mean & Median & Min & Max & Std Dev \\
\hline AMD & 14 & 141 & 108 & 21 & 550 & 123 \\
\hline GLD & 13 & 2540 & 770 & 200 & 9500 & 2800 \\
\hline GLD (LAW) & 6 & 11300 & 8400 & 310 & 23000 & 7800 \\
\hline GLD (Ambiguous) & 8 & 630 & 202 & 11 & 1950 & 720 \\
\hline Iron (Fe) - mg/L & number of sites & Mean & Median & Min & Max & Std Dev \\
\hline AMD & 143 & 48 & 33 & 0.05 & 512 & 63 \\
\hline GLD & 10 & 2 & 0.9 & 0.1 & 6.6 & 2.1 \\
\hline GLD (LAW) & 8 & 0.1 & 0.1 & 0.01 & 0.6 & 0.2 \\
\hline GLD (Ambiguous) & 5 & 6.2 & 4.1 & 1.2 & 17.5 & 5.8 \\
\hline Manganese (Mn) - mg/L & number of sites & Mean & Median & Min & Max & Std Dev \\
\hline AMD & 143 & 5.3 & 2.3 & 0.02 & 74 & 10.1 \\
\hline GLD & 10 & 0.7 & 0.3 & 0.01 & 2 & 0.7 \\
\hline GLD (LAW) & 8 & 0.07 & 0.06 & 0.02 & 0.2 & 0.04 \\
\hline GLD (Ambiguous) & 5 & 0.6 & 0.6 & 0.4 & 0.9 & 0.2 \\
\hline Sulfate - mg/L & number of sites & Mean & Median & Min & Max & Std Dev \\
\hline AMD & 146 & 595 & 510 & 34 & 2000 & 405 \\
\hline GLD & 10 & 4.5 & 3.9 & 0.4 & 9.1 & 3.2 \\
\hline GLD (LAW) & 8 & 3.1 & 2.3 & 0.4 & 9.3 & 2.8 \\
\hline GLD (Ambiguous) & 6 & 2.5 & 2 & 0.9 & 5.9 & 1.7 \\
\hline Chloride (Cl) - mg/L & number of sites & Mean & Median & Min & Max & Std Dev \\
\hline AMD & 145 & 26 & 7.8 & 0.1 & 460 & 58 \\
\hline GLD & 10 & 8.8 & 2.8 & 0.4 & 33 & 10.6 \\
\hline GLD (LAW) & 8 & 470 & 77 & 14.1 & 3300 & 1060 \\
\hline GLD (Ambiguous) & 6 & 3.1 & 1 & 0.5 & 14.3 & 5 \\
\hline $\mathrm{SPC}-\mu \mathrm{s} / \mathrm{cm}$ & number of sites & Mean & Median & Min & Max & Std Dev \\
\hline AMD & 143 & 1367 & 1290 & 131 & 3980 & 732 \\
\hline GLD & 8 & 180 & 120 & 70 & 360 & 111 \\
\hline GLD (LAW) & 6 & 2300 & 700 & 250 & 10500 & 3690 \\
\hline GLD (Ambiguous) & 0 & - & - & - & - & - \\
\hline Bromide (Br) - mg/L & number of sites & Mean & Median & Min & Max & Std Dev \\
\hline AMD & 146 & 0.1 & 0.04 & 0.004 & 0.7 & 0.1 \\
\hline GLD & 9 & 0.1 & 0.1 & 0.01 & 0.2 & 0.1 \\
\hline GLD (LAW) & 6 & 1.2 & 1 & 0.5 & 2.2 & 0.7 \\
\hline GLD (Ambiguous) & 6 & 0.1 & 0.1 & 0.1 & 0.2 & 0.04 \\
\hline Barium (Ba) - mg/L & number of sites & Mean & Median & Min & Max & Std Dev \\
\hline AMD & 143 & 0.02 & 0.02 & 0.002 & 0.04 & 0 \\
\hline GLD & 10 & 0.4 & 0.1 & 0.01 & 3.1 & 1 \\
\hline GLD (LAW) & 8 & 1 & 0.8 & 0.4 & 2.2 & 1 \\
\hline GLD (Ambiguous) & 5 & 0.2 & 0.2 & 0.1 & 0.3 & 0 \\
\hline Calcium (Ca) - mg/L & number of sites & Mean & Median & Min & Max & Std Dev \\
\hline AMD & 143 & 102 & 89 & 3.3 & 410 & 71 \\
\hline GLD & 10 & 12.4 & 9.3 & 4.6 & 29 & 8.4 \\
\hline GLD (LAW) & 8 & 20 & 17.8 & 9.7 & 33 & 6.9 \\
\hline GLD (Ambiguous) & 5 & 8.2 & 8.5 & 4.2 & 12.6 & 2.9 \\
\hline Magnesium (Mg) - mg/L & number of sites & Mean & Median & Min & Max & Std Dev \\
\hline AMD & 143 & 45 & 38 & 3.6 & 210 & 31 \\
\hline GLD & 10 & 3.6 & 3.5 & 0.6 & 7.6 & 2 \\
\hline GLD (LAW) & 8 & 3.5 & 3.5 & 1.7 & 6 & 1.2 \\
\hline GLD (Ambiguous) & 5 & 2.3 & 2.5 & 1.5 & 3.1 & 0.5 \\
\hline pH & number of sites & Mean & Median & Min & Max & Std Dev \\
\hline AMD & 145 & 5 & 5.2 & 2.7 & 7.3 & 1.3 \\
\hline GLD & 10 & 6.6 & 6.3 & 6 & 9.1 & 0.9 \\
\hline GLD (LAW) & 8 & 7.5 & 7.8 & 6 & 8.3 & 0.8 \\
\hline GLD (Ambiguous) & 5 & 6.1 & 6 & 6 & 6.7 & 0.3 \\
\hline
\end{tabular}




\section{References}

Akcil, A., Koldas, S., 2006. Acid Mine Drainage (AMD): causes, treatment and case studies. J. Clean. Prod. 14, 1139-1145. https://doi.org/10.1016/j.jclepro.2004.09.006

Blothe, M., Roden, E.E., 2009. Microbial Iron Redox Cycling in a Circumneutral-pH Groundwater Seep. Appl. Environ. Microbiol. 75, 468-473. https://doi.org/10.1128/AEM.01817-08

Brantley, S.L., Yoxtheimer, D., Arjmand, S., Grieve, P., Vidic, R., Pollak, J., Llewellyn, G.T., Abad, J., Simon, C., 2014. Water resource impacts during unconventional shale gas development: The Pennsylvania experience. Int. J. Coal Geol. 126, 140-156. https://doi.org/10.1016/j.coal.2013.12.017

Bruun, A., Finster, K., Gunnlaugsson, H.P., NØrnberg, P., Friedrich, M.W., 2010. A Comprehensive Investigation on Iron Cycling in a Freshwater Seep Including Microscopy, Cultivation and Molecular Community Analysis. Geomicrobiol. J. 27, 15-34. https://doi.org/10.1080/01490450903232165

Burrows, J.E., Peters, S.C., Cravotta, C.A., 2015. Temporal geochemical variations in above- and belowdrainage coal mine discharge. Appl. Geochemistry 62, 84-95. https://doi.org/10.1016/j.apgeochem.2015.02.010

Cahill, A.G., Parker, B.L., Mayer, B., Mayer, K.U., Cherry, J.A., 2018. High resolution spatial and temporal evolution of dissolved gases in groundwater during a controlled natural gas release experiment. Sci. Total Environ. 622-623, 1178-1192. https://doi.org/10.1016/j.scitotenv.2017.12.049

Cahill, A.G., Steelman, C.M., Forde, O., Kuloyo, O., Emil Ruff, S., Mayer, B., Ulrich Mayer, K., Strous, M., Cathryn Ryan, M., Cherry, J.A., Parker, B.L., 2017. Mobility and persistence of methane in groundwater in a controlled-release field experiment. Nat. Geosci. 10, 289-294. https://doi.org/10.1038/ngeo2919

Carter, K.M., Harper, J.A., Schmid, K.W., Kostelnik, J., 2011. Unconventional natural gas resources in Pennsylvania: The backstory of the modern Marcellus Shale play. Environ. Geosci. 18, 217-257. https://doi.org/10.1306/eg.09281111008

Christian, K.M., Lautz, L.K., Hoke, G.D., Siegel, D.I., Lu, Z., Kessler, J., 2016. Methane occurrence is associated with sodium-rich valley waters in domestic wells overlying the Marcellus shale in New York State. Water Resour. Res. 52, 206-226. https://doi.org/10.1002/2015WR017805

Cote, M., Collings, R., Pilcher, R.C., Talkington, C., Franklin, P., 2004. Methane Emissions from Abandoned Coal Mines in the United States: Emissino Inventory Methodology and 1990 - 2002 Emissions Estimates.

Cravotta, C.A., 2008. Dissolved metals and associated constituents in abandoned coal-mine discharges, Pennsylvania, USA. Part 2: Geochemical controls on constituent concentrations. Appl. Geochemistry 23, 203-226. https://doi.org/10.1016/j.apgeochem.2007.10.003

Darrah, T.H., Vengosh, A., Jackson, R.B., Warner, N.R., Poreda, R.J., 2014. Noble gases identify the mechanisms of fugitive gas contamination in drinking-water wells overlying the Marcellus and Barnett Shales. Proc. Natl. Acad. Sci. 111, 14076-14081. https://doi.org/10.1073/pnas.1322107111

Davies, R.J., Almond, S., Ward, R.S., Jackson, R.B., Adams, C., Worrall, F., Herringshaw, L.G., Gluyas, J.G., Whitehead, M.A., 2014. Oil and gas wells and their integrity: Implications for shale and unconventional resource exploitation. Mar. Pet. Geol. 56, 239-254. https://doi.org/10.1016/j.marpetgeo.2014.03.001

de Angelis, M.A., Lilley, M.D., 1987. Methane in surface waters of Oregon estuaries and rivers1. Limnol. Oceanogr. 32, 716-722. https://doi.org/10.4319/1o.1987.32.3.0716

Dilmore, R.M., Sams, J.I., Glosser, D., Carter, K.M., Bain, D.J., 2015. Spatial and Temporal Characteristics of Historical Oil and Gas Wells in Pennsylvania: Implications for New Shale Gas Resources. Environ. Sci. Technol. 49, 12015-12023. https://doi.org/10.1021/acs.est.5b00820

Dresel, P., Rose, A., 2010. Chemistry and origin of oil and gas well brines in western Pennsylvania. Pennsylvania Geol. Surv., 4th Ser. Open ... 48. https://doi.org/Open-File Report OFOG 1001.0

Gorody, A.W., 2012. Factors affecting the variability of stray gas concentration and composition in groundwater. Environ. Geosci. 19, 17-31. https://doi.org/10.1306/eg.12081111013 
Grieve, P.L., 2014. Measuring concentrations of dissolved natural gas in three streams in Pennsylvania to estimate methane fluxes from the subsurface. M.S Thesis. The Pennsylvania State University.

Grieve, P.L., Hynek, S.A., Heilweil, V., Sowers, T., Llewellyn, G., Yoxtheimer, D., Solomon, D.K., Brantley, S.L., 2018. Using environmental tracers and modelling to identify natural and gas wellinduced emissions of methane into streams. Appl. Geochemistry 91, 107-121. https://doi.org/10.1016/j.apgeochem.2017.12.022

Haluszczak, L.O., Rose, A.W., Kump, L.R., 2013. Geochemical evaluation of flowback brine from Marcellus gas wells in Pennsylvania, USA. Appl. Geochemistry 28, 55-61. https://doi.org/10.1016/j.apgeochem.2012.10.002

Hammond, P.A., Wen, T., Brantley, S.L., Engelder, T., 2020. Gas well integrity and methane migration: evaluation of published evidence during shale-gas development in the USA. Hydrogeol. J. https://doi.org/10.1007/s10040-020-02116-y

Harkness, J.S., Darrah, T.H., Warner, N.R., Whyte, C.J., Moore, M.T., Millot, R., Kloppmann, W., Jackson, R.B., Vengosh, A., 2017. The geochemistry of naturally occurring methane and saline groundwater in an area of unconventional shale gas development. Geochim. Cosmochim. Acta 208, 302-334. https://doi.org/10.1016/j.gca.2017.03.039

Hedin, R.S., Stafford, S.L., Weaver, T.J., 2005. Acid Mine Drainage Flowing from Abandoned Gas Wells. Mine Water Environ. 24, 104-106. https://doi.org/10.1007/s10230-005-0077-z

Heilweil, V.M., Grieve, P.L., Hynek, S.A., Brantley, S.L., Solomon, D.K., Risser, D.W., 2015. Stream Measurements Locate Thermogenic Methane Fluxes in Groundwater Discharge in an Area of ShaleGas Development. Environ. Sci. Technol. 49, 4057-4065. https://doi.org/10.1021/es503882b

Heilweil, V.M., Risser, D.W., Conger, R.W., Grieve, P.L., USGS, Heilweil, V.M., Risser, D.W., Conger, R.W., Grieve, P.L., 2014. Estimation of methane concentrations and loads in groundwater discharge to Sugar Run, Lycoming County, Pennsylvania. Open-File Rep. https://doi.org/10.3133/ofr20141126

Heilweil, V.M., Stolp, B.J., Kimball, B.A., Susong, D.D., Marston, T.M., Gardner, P.M., 2013. A streambased methane monitoring approach for evaluating groundwater impacts associated with unconventional gas development. Groundwater 51, 511-524. https://doi.org/10.1111/gwat.12079

Humphrey, C., Blackmon, J., Kelley, T., ODriscoll, M., Iverson, G., 2018. Environmental Health Threats Associated with Drainage from a Coastal Urban Watershed. Environ. Nat. Resour. Res. 8, 52. https://doi.org/10.5539/enrr.v8n1p52

Jones, J.B., Mulholland, P.J., 1998. Methane input and evasion in a hardwood forest stream: Effects of subsurface flow from shallow and deep pathway. Limnol. Oceanogr. 43, 1243-1250. https://doi.org/10.4319/1o.1998.43.6.1243

Jones, V.T., Drozd, R.J., 1979. Predictions of Oil or Gas Potential by Near-Surface Geochemistry: ABSTRACT. Am. Assoc. Pet. Geol. Bull. 63, 932-952. https://doi.org/10.1306/2F91828E-16CE11D7-8645000102C1865D

Kang, M., Christian, S., Celia, M.A., Mauzerall, D.L., Bill, M., Miller, A.R., Chen, Y., Conrad, M.E., Darrah, T.H., Jackson, R.B., 2016. Identification and characterization of high methane-emitting abandoned oil and gas wells. Proc. Natl. Acad. Sci. U. S. A. 113, 13636-13641. https://doi.org/10.1073/pnas.1605913113

Kang, M., Kanno, C.M., Reid, M.C., Zhang, X., Mauzerall, D.L., Celia, M.A., Chen, Y., Onstott, T.C., 2014. Direct measurements of methane emissions from abandoned oil and gas wells in Pennsylvania. Proc. Natl. Acad. Sci. USA 111, 18173-18177.

Kirchgessner, D.A., Piccot, S.D., Masemore, S.S., 2000. An Improved Inventory of Methane Emissions from Coal Mining in the United States. J. Air Waste Manage. Assoc. 50, 1904-1919. https://doi.org/10.1080/10473289.2000.10464227

Krause, E., Pokryszka, Z., 2013. Investigations on Methane Emission from Flooded Workings of Closed Coal Mines. J. Sustain. Min. 12, 40-45. https://doi.org/10.7424/jsm130206

Kreuzer, R.L., Darrah, T.H., Grove, B.S., Moore, M.T., Warner, N.R., Eymold, W.K., Whyte, C.J., Mitra, G., Jackson, R.B., Vengosh, A., Poreda, R.J., 2018. Structural and Hydrogeological Controls on Hydrocarbon and Brine Migration into Drinking Water Aquifers in Southern New York. Groundwater 
56, 225-244. https://doi.org/10.1111/gwat.12638

Llewellyn, G.T., 2014. Evidence and mechanisms for Appalachian Basin brine migration into shallow aquifers in NE Pennsylvania, USA. Hydrogeol. J. 22, 1055-1066.

Llewellyn, G.T., Dorman, F., Westland, J.L., Yoxtheimer, D., Grieve, P., Sowers, T., Humston-Fulmer, E., Brantley, S.L., 2015. Evaluating a groundwater supply contamination incident attributed to Marcellus Shale gas development. Proc. Natl. Acad. Sci. 112, 6325-6330. https://doi.org/10.1073/pnas.1420279112

Maasakkers, J.D., Jacob, D.J., Sulprizio, M.P., Turner, A.J., Weitz, M., Wirth, T., Hight, C., DeFigueiredo, M., Desai, M., Schmeltz, R., Hockstad, L., Bloom, A.A., Bowman, K.W., Jeong, S., Fischer, M.L., 2016. Gridded National Inventory of U.S. Methane Emissions. Environ. Sci. Technol. 50, 1312313133. https://doi.org/10.1021/acs.est.6b02878

Molofsky, L.J., Connor, J.A., McHugh, T.E., Richardson, S.D., Woroszylo, C., Alvarez, P.J., 2016. Environmental Factors Associated With Natural Methane Occurrence in the Appalachian Basin. Groundwater 54, 656-668. https://doi.org/10.1111/gwat.12401

Myhre, G., Shindell, D., Breon, F.., Collins, W., Fuglestvedt, J., J, H., Koch, D., Lamarque, J., Lee, D., Mendoza, B., 2013. Anthropogenic and natural radiative forcing, in: Climatic Change. pp. 659-740.

Oil and Gas Wells, Drilling Regulating Act of May 17, 1921, 1921.

Omara, M., Sullivan, M.R., Li, X., Subramian, R., Robinson, A.L., Presto, A.A., 2016. Methane Emissions from Conventional and Unconventional Natural Gas Production Sites in the Marcellus Shale Basin. Environ. Sci. Technol. 50, 2099-2107. https://doi.org/10.1021/acs.est.5b05503

Osborn, S.G., Vengosh, A., Warner, N.R., Jackson, R.B., 2011. Methane contamination of drinking water accompanying gas-well drilling and hydraulic fracturing. Proc. Natl. Acad. Sci. 108, 8172-8176. https://doi.org/10.1073/pnas.1100682108

Pennsylvania Department of Environmental Protection, 2018a. PA DEP eMAP [WWW Document]. URL http://www.depgis.state.pa.us/emappa/ (accessed 1.1.18).

Pennsylvania Department of Environmental Protection, 2018b. PA DEP SPUD Data Report [WWW Document].

URL http://www.depreportingservices.state.pa.us/ReportServer/Pages/ReportViewer.aspx?/Oil_Gas/Spud _External_Data (accessed 1.1.18).

Pennsylvania Department of Environmental Protection, 2018c. Abandoned, Orphan \& DEP Plugged Wells Listing [WWW Document]. URL http://www.depreportingservices.state.pa.us/ReportServer/Pages/ReportViewer.aspx?/Oil_Gas/Aban doned_Orphan_Web (accessed 1.28.19).

Pennsylvania Department of Environmental Protection, 2018d. Pennsylvania Digitized Mined Areas [WWW Document]. URL http://www.pasda.psu.edu/uci/DataSummary.aspx?dataset=257 (accessed 7.13.18).

Pennsylvania Department of Environmental Protection, 2018e. PA Oil and Gas Mapping [WWW Document]. URL http://www.depgis.state.pa.us/PaOilAndGasMapping (accessed 1.1.18).

Reese, S.O., Neboga, V. V, Pelepko, S., Kosmer, W.J., Beattie, S., 2014. GROUNDWATER AND PETROLEUM RESOURCES OF SULLIVAN COUNTY, PENNSYLVANIA. Water Resource Report.

Révész, K.M., Breen, K.J., Baldassare, A.J., Burruss, R.C., 2012. Carbon and hydrogen isotopic evidence for the origin of combustible gases in water-supply wells in north-central Pennsylvania. Appl. Geochemistry 27, 361-375. https://doi.org/10.1016/j.apgeochem.2011.12.002

Roden, E.E., McBeth, J.M., Blöthe, M., Percak-Dennett, E.M., Fleming, E.J., Holyoke, R.R., Luther, G.W., Emerson, D., Schieber, J., 2012. The Microbial Ferrous Wheel in a Neutral pH Groundwater Seep. Front. Microbiol. 3. https://doi.org/10.3389/fmicb.2012.00172

Rose, A., Cravotta, C., 1998. Coal Mine Drainage Prediction and Pollution Preventiona in Pennsylvania, The Pennsylvania Department of Environmental Protection.

Ross, P.W., 1996. Allegheny oil: The historic petroleum industry on the Allegheny National Forest. USDA Forest Service, Eastern Region. 
Schimmelmann, A., Ensminger, S.A., Drobniak, A., Mastalerz, M., Etiope, G., Jacobi, R.D., Frankenberg, C., 2018. Natural geological seepage of hydrocarbon gas in the Appalachian Basin and Midwest USA in relation to shale tectonic fracturing and past industrial hydrocarbon production. Sci. Total Environ. 644, 982-993. https://doi.org/10.1016/j.scitotenv.2018.06.374

Schoell, M., 1980. The hydrogen and carbon isotopic composition of methane from natural gases of various origins. Geochim. Cosmochim. Acta 44, 649-661. https://doi.org/10.1016/0016-7037(80)90155-6

Siegel, D., Smith, B., Perry, E., Bothun, R., Hollingsworth, M., 2016. Dissolved methane in shallow groundwater of the Appalachian Basin: Results from the Chesapeake Energy predrilling geochemical database. Environ. Geosci. 23, 1-47. https://doi.org/10.1306/eg.01051615015

Siegel, D.I., Azzolina, N.A., Smith, B.J., Perry, A.E., Bothun, R.L., 2015a. Methane Concentrations in Water Wells Unrelated to Proximity to Existing Oil and Gas Wells in Northeastern Pennsylvania. Environ. Sci. Technol. 49, 4106-4112. https://doi.org/10.1021/es505775c

Siegel, D.I., Smith, B., Perry, E., Bothun, R., Hollingsworth, M., 2015b. Pre-drilling water-quality data of groundwater prior to shale gas drilling in the Appalachian Basin: Analysis of the Chesapeake Energy Corporation dataset. Appl. Geochemistry 63, 37-57. https://doi.org/10.1016/j.apgeochem.2015.06.013

Stanley, E.H., Casson, N.J., Christel, S.T., Crawford, J.T., Loken, L.C., Oliver, S.K., 2016. The ecology of methane in streams and rivers: Patterns, controls, and global significance. Ecol. Monogr. 86, 146171. https://doi.org/10.1890/15-1027

Townsend-Small, A., Ferrara, T.W., Lyon, D.R., Fries, A.E., Lamb, B.K., 2016. Emissions of coalbed and natural gas methane from abandoned oil and gas wells in the United States. Geophys. Res. Lett. 43, 2283-2290. https://doi.org/10.1002/2015GL067623

U. S. National Research Council, 2010. Management and Effects of Coalbed Methane Produced Water in the Western United States, Management and Effects of Coalbed Methane Produced Water in the Western United States. https://doi.org/10.17226/12915

U.S. Environmental Protection Agency, 2016. Hydraulic Fracturing for Oil and Gas: Impacts from the Hydraulic Fracturing Water Cycle on Drinking Water Resources in the United States.

Vengosh, A., Jackson, R.B., Warner, N., Darrah, T.H., Kondash, A., 2014. A critical review of the risks to water resources from unconventional shale gas development and hydraulic fracturing in the United States. Environ. Sci. Technol. https://doi.org/10.1021/es405118y

Vesper, D.J., Moore, J.E., Adams, J.P., 2016. Inorganic carbon dynamics and CO2 flux associated with coal-mine drainage sites in Blythedale PA and Lambert WV, USA. Environ. Earth Sci. 75, 340. https://doi.org/10.1007/s12665-015-5191-z

Warner, N.R., Jackson, R.B., Darrah, T.H., Osborn, S.G., Down, A., Zhao, K., White, A., Vengosh, A., 2012. Geochemical evidence for possible natural migration of Marcellus Formation brine to shallow aquifers in Pennsylvania. Proc. Natl. Acad. Sci. 109, 11961-11966. https://doi.org/10.1073/pnas.1121181109

Wen, T., Castro, M.C., Nicot, J.-P., Hall, C.M., Larson, T., Mickler, P., Darvari, R., 2016. Methane Sources and Migration Mechanisms in Shallow Groundwaters in Parker and Hood Counties, Texas-A Heavy Noble Gas Analysis. Environ. Sci. Technol. 50, 12012-12021. https://doi.org/10.1021/acs.est.6b01494

Wen, T., Castro, M.C., Nicot, J.P., Hall, C.M., Pinti, D.L., Mickler, P., Darvari, R., Larson, T., 2017. Characterizing the Noble Gas Isotopic Composition of the Barnett Shale and Strawn Group and Constraining the Source of Stray Gas in the Trinity Aquifer, North-Central Texas. Environ. Sci. Technol. 51, 6533-6541. https://doi.org/10.1021/acs.est.6b06447

Wen, T., Niu, X., Gonzales, M., Zheng, G., Li, Z., Brantley, S.L., 2018. Big Groundwater Data Sets Reveal Possible Rare Contamination Amid Otherwise Improved Water Quality for Some Analytes in a Region of Marcellus Shale Development. Environ. Sci. Technol. 52, 7149-7159. https://doi.org/10.1021/acs.est.8b01123

Wen, T., Woda, J., Marcon, V., Niu, X., Li, Z., Brantley, S.L., 2019. Exploring How to Use Groundwater Chemistry to Identify Migration of Methane near Shale Gas Wells in the Appalachian Basin. Environ. 
Sci. Technol. acs.est.9b02290. https://doi.org/10.1021/acs.est.9b02290

Wendt, A.K., Sowers, T., Hynek, S., Lemon, J., Beddings, E., Zheng, G., Li, Z., Williams, J.Z., Brantley, S.L., 2018. Scientist-Nonscientist Teams Explore Methane Sources in Streams Near Oil/Gas Development. J. Contemp. Water Res. Educ. 164, 80-111. https://doi.org/10.1111/j.1936704X.2018.03286.X

Whiticar, M.J., 1999. Carbon and hydrogen isotope systematics of bacterial formation and oxidation of methane. Chem. Geol. 161, 291-314. https://doi.org/10.1016/S0009-2541(99)00092-3

Woda, J., Wen, T., Oakley, D., Yoxtheimer, D., Engelder, T., Castro, M.C., Brantley, S.L., 2018. Detecting and explaining why aquifers occasionally become degraded near hydraulically fractured shale gas wells. Proc. Natl. Acad. Sci. 115, 12349-12358. https://doi.org/10.1073/pnas.1809013115 